\title{
Monitoring Vibration of A Model of Rotating Machine
}

\author{
Arko Djajadi, Arsi Azavi, Rusman Rusyadi, Erikson Sinaga \\ Mechatronics Department, Faculty of Engineering, Swiss German University (SGU) \\ EduTown BSDCity, Tangerang 15339, Indonesia \\ arko@sgu.ac.id
}

Received: April 27 $7^{\text {th }}$ 2011; Revised: May 3 ${ }^{\text {rd }}, 2011$; Accepted: June 15 ${ }^{\text {th }}, 2011$; Published online: July $7^{\text {th }}, 2011$.

\begin{abstract}
Abstrak
Pergerakan mekanis benda atau perputaran mesin putar cenderung menyebabkan getaran tambahan. Divais sensor getaran perlu dipasang untuk memonitor tingkat getaran secara kontinyu pada sebuah sistem yang melibatkan mesin putar. Sensor ini diperlukan karena frekuensi dan amplitude getaran tidak dapat dengan mudah diukur secara kuantitatif hanya melalui pengamatan dengan mata manusia atau dengan rabaan tangan. Apabila sinyal getaran dari sistem dengan mesin putar mengadung banyak derau, kemungkinan besar sistem tersebut mengalami gangguan yang dapat berlanjut menjadi kegagalan atau kerusaan lebih parah. Dalam proyek riset eksperimen ini, sebuah model struktur telah dibuat untuk mensimulasikan getaran dan melakukan pengukuran dan monitor kinerja struktur dari segi tingkat getaran yang ditimbulkan pada saat putaran dengan kondisi seimbang dan tidak seimbang.Dalam model terskala ini, sinyal luaran dari sensor getaran diproses awal dalam mikrokontroler dan dikirimkan hasilnya ke PC melalui saluran serial untuk diplotkan ke layar dengan menggunakan perangkat lunak yang dibuat dalam bahasa C. Bentuk gelombang sinyal dapat dipakai untuk analisis getaran lebih lanjut.Batas tingkat getaran maksimum dapat diatur dalam mikrokontroller yang memungkinkan sistem mesin putar dimatikan dalam kondisi getaran yang berlebihan untuk mengurangi tingkat kerusakan yang ditimbulkan. Hasil dari eksperimen menunjukkan kesesuaian dengan teori bahwa kondisi tidak seimbang pada putaran mesin dapat menimbulkan getaran yang lebih besar dibandingkan dengan kondisi seimbang. Penambahan dan pengurangan massa untuk penyeimbang dapat dilakukan untuk mendapatkan kondisi getaran yang lebih rendah.
\end{abstract}

Kata kunci: Sensor getaran mekanik, mikrokontroler, perangkat lunak plot, model terskala, monitoring.

\begin{abstract}
Mechanical movement or motion of a rotating machine normally causes additional vibration. A vibration sensing device must be added to constantly monitor vibration level of the system having a rotating machine, since the vibration frequency and amplitude cannot be measured quantitatively by only sight or touch. If the vibration signals from the machine have a lot of noise, there are possibilities that the rotating machine has defects that can lead to failure. In this experimental research project, a vibration structure is constructed in a scaled model to simulate vibration and to monitor system performance in term of vibration level in case of rotation with balanced and unbalanced condition. In this scaled model, the output signal of the vibration sensor is processed in a microcontroller and then transferred to a computer via a serial communication medium, and plotted on the screen with data plotter software developed using $C$ language. The signal waveform of the vibration is displayed to allow further analysis of the vibration. Vibration level monitor can be set in the microcontroller to allow shutdown of the rotating machine in case of excessive vibration to protect the rotating machine from further damage. Experiment results show the agreement with theory that unbalance condition on a rotating machine can lead to larger vibration amplitude compared to balance condition. Adding and reducing the mass for balancing can be performed to obtain lower vibration level.
\end{abstract}

Keywords: Mechanical vibration sensor, microcontroller, data plotter software, scaled model, monitoring.

\section{INTRODUCTION}

Vibration analysis [1] is one of the most important conditions monitoring techniques that are applied in real life, as more and more indispensible rotating machines are found in daily life. ISO 13373-1: 2001 states that the monitoring condition and diagnostic of machines, in this case the vibration monitoring, must be seriously considered to avoid machine faults or defects [9]. Most of the defects encountered in such rotating machinery give different vibration patterns where mostly faults can be identified by using vibration analysis techniques. The need of vibration monitoring in rotating machine is part of regular maintenance program to keep the machinery work properly and to avoid any damage. Therefore, low cost vibration monitoring system to address such cases is justified and must be made available.

Vibration measurement system in this experimental research includes vibration sensors to convert mechanical movement to electrical 
signal, signal amplifiers to improve signal level, data acquisition device (i.e. ADC of the microcontroller) and PC for signal analysis and display. Usually machine vibrations are estimated by measuring the displacement, velocity or acceleration.

Displacement sensor is used for measurement of relative motion between two surfaces or objects (i.e. rotating shaft and machine base). Mathematically, the velocity is time derivative of displacement, while the acceleration is time derivative of velocity [2].

In the system of the rotating machine, the measurement of vibration can be achieved by many different types of sensors, one of them is accelerometer [3][5][6][7][8]. A particular type of accelerometer commonly employed is piezoelectric accelerometers, while other type is thermal accelerometer. Once the acceleration is measured, other vibration quantities can be calculated theoretically. The machine displacement or vibration speed can be calculated by integration of the acceleration signal.

The vibration monitoring system as an embedded system to the rotating machines is represented in the following Figure1. It consists of the rotating machine under inspection, the accelerometer attached as the vibration sensor, data acquisition system using microcontroller and PC for further analysis and plotting.

In Figure 1, first step, the rotating machine vibration will be measured by accelerometers with different axis orientation. Next, the signal from the sensor will be sent to the microcontroller. In the microcontroller the data will be processed, then transferred to a computer via a serial communication, and the signal is plotted using C++ Builder Data Plotter.

In this experimental research project, a vibration structure including its embedded system is constructed in a scaled model with a purpose to simulate vibration and to monitor system performance in term of vibration level in case of rotation with balance and unbalance conditions. This can be used as a base of modelling and later on can be extended to many fields related to vibration system.

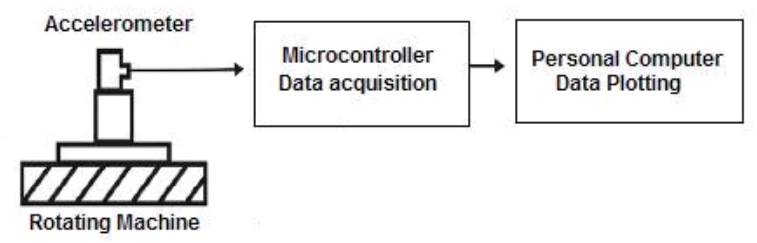

Figure 1. Block diagram of the vibration monitoring system.

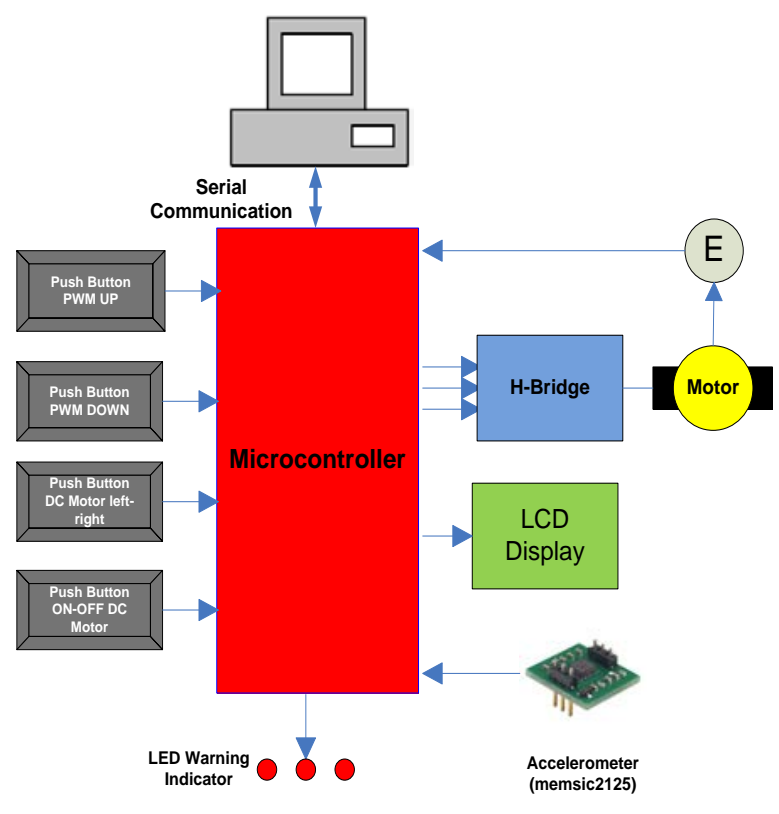

Figure 2. System design overview.

\section{SySTEM DESIGN}

All the system is controlled by ATmega 8535 microcontroller. From the Figure 2 there are four push buttons to control the system. The first push button is for increasing the speed of the motor. The second push button is for decreasing the speed of the motor. The last two push buttons are to control the direction of the motor and to turn on-off the motor.

To control the direction of the motor, EMS (Embedded Module System) 5A H-Bridge is used. With this circuit the speed of the motor can be controlled by using PWM (Pulse Width Modulation) technique. Encoder is also required to know the speed of the motor, then LCD (Liquid Crystal Display) is used for displaying the direction and the RPM (Rotation per Minute) of the motor.

The vibration sensor (Memsic2125 Accelerometer) has two axes to sense the acceleration of the machine when the machine is rotated. The Memsic 2125 is a low-cost thermal accelerometer capable of measuring tilt, collision, static and dynamic acceleration, rotation, and vibration with a range of $\pm 3 \mathrm{~g}$ on two axes with output in $100 \mathrm{~Hz}$ PWM having duty cycle proportional to acceleration [4]. The Memsic2125 accelerometer contains a small heater. This heater warms a "bubble" of air within the device. When gravitational forces act on this bubble, it moves. This movement is detected by a very sensitive temperature sensor and the onboard electronics convert the bubble relative position to the $\mathrm{g}$ forces, and into pulse outputs for the $\mathrm{x}$ and $\mathrm{y}$ axis. 
Software is one of the most important parts in the system; it can be used for controlling all the system. In this experimental research, all the system is controlled by using ATmega 8535 while for the data plotter it is using personal computer (PC) to show the data from measurement.

First, the microcontroller is initialized. Settings, such as LCD configuration, port initialization, baud rate value, are performed according to the requirement in the flow chart and its program listing.

After initialization, the microcontroller is programmed to monitor all the inputs and gives control signal to output devices. The primary input in this system is the signal from accelerometer that must be acquired in the microcontroller. Once the motor is turned on, the accelerometer will measure the vibration from the rotating machine.

Then, the data will be transferred to PC via serial to USB converter. In the PC, after the $\mathrm{C}++$ Builder Data Plotter program initializes some parameters, such as baud rate and communication port, data from the microcontroller are captured. The accelerometer data from microcontroller are processed, and converted in real time. Then the data is plotted using the $\mathrm{C}++$ Builder Data Plotter software.

The other microcontroller inputs are from the push buttons to control the system when the rotating machine was rotated. All the push buttons information will be display in the LCD, such as the RPM speed of the motor, the direction of the rotating machine and also the increase or decrease of the speed of the rotating machine. Figure 3 shows the program flowchart of the system, within microcontroller (left) and within PC (right).

The vibration data from the sensor will be processed in the microcontroller and displayed on the PC using C++ Builder Data Plotter program. Figure 4 shows the data plotter display. The system also provides the alarm signal to give a warning message and LED (Light Emitting Diode) warning to the user in case the system of the rotating machine has failures due to excessive vibration amplitude.

\section{RESULT OF MEASUREMENT}

The output signal from the Memsic2125 accelerometer is pulse width modulated (PWM) signal. The pulse output from the Memsic2125 accelerometer is set to $50 \%$ duty cycle at $0 \mathrm{~g}$. T1 is the output from Xout or Yout; T2 is calibrated to 10 milliseconds at $25^{\circ} \mathrm{C}$ (room temperature). $\mathrm{T} 1$ and $\mathrm{T} 2$ are used to get the $\mathrm{g}$ value using the $\mathrm{g}$

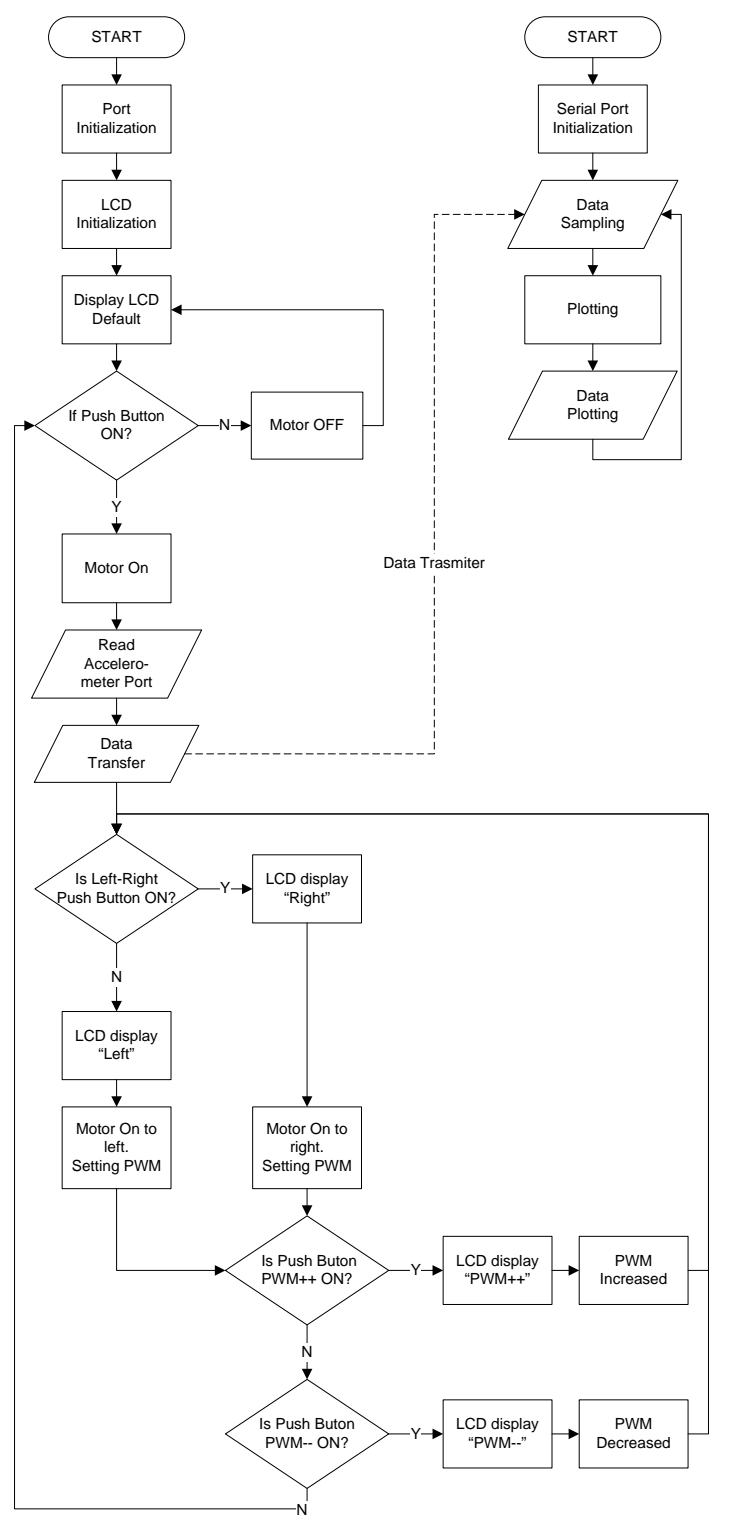

Figure 3. The flowchart of the program.

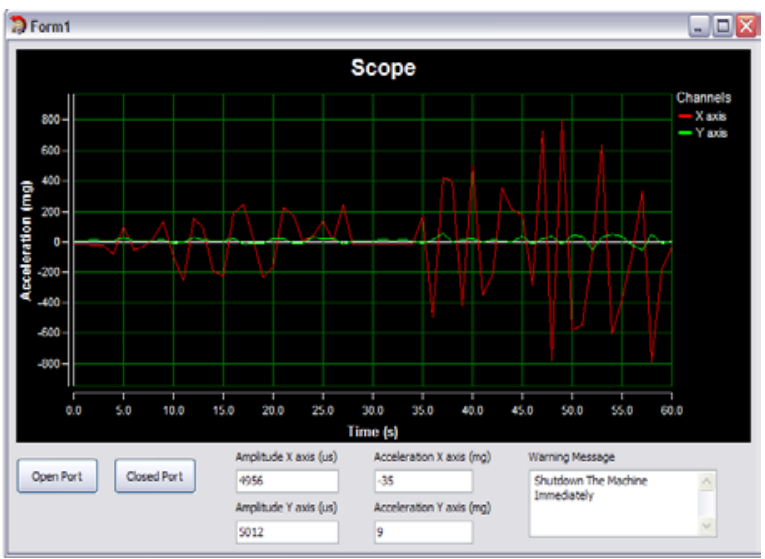

Figure 4. C++ builder data plotter.

formula (1) for the Memsic2125, referring to Figure 5 of its pulse modulated output. The formula for the acceleration a in $g$ is [4]:

$$
a(g)=((T 1 / T 2)-0.5) / 12.5 \%
$$




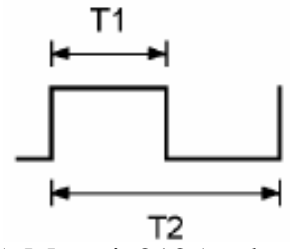

Figure 5. Memsic2125 pulse output.

After several testing with the condition of the rotating machine, the results of data measurement $\mathrm{g}$ from the Memsic2125 accelerometer are shown in Table 1 and Table 2. All the results of the acceleration have been converted to $\mathrm{mg}$ (for gravitation where $1 \mathrm{~g}=1000 \mathrm{mg}=9.81 \mathrm{~m} / \mathrm{s} 2$ ).

The unbalance condition from the rotating machine is achieved by adding the unbalance mass on the end of the rotating shaft. The unbalance location from the rotating machine is show in figure 6 , several points along the shaft.

The range of the sensor measurement in balance condition is between $251 \mathrm{mg}$ and -244 mg (for $\mathrm{x}$ axis); between $72 \mathrm{mg}$ and -40 (for $\mathrm{y}$ axis). Meanwhile, unbalance condition is between $348 \mathrm{mg}$ and -316 $\mathrm{mg}$ (for $\mathrm{x}$ axis); between $72 \mathrm{mg}$ and -192 $\mathrm{mg}$ (for y axis), which is higher than in balance condition by a factor between 1.2 to 1.5 for $\mathrm{x}$-axis and between 1 to 4.8 for $y$-axis in this case.

Figure 7 shows the data output of accelerometer in balance condition; it means no additional mass on the system of the rotating machine.

Further analysis of the graphs in Figure 7 and 8 , it is found that the maximum vibration amplitudes along the $\mathrm{x}$-axis (along the shaft) during balance and unbalance conditions show similar patterns and increase in amplitude which mainly due to the inperfect rubbler coupling between the motor and the shaft. Meanwhile, the maximum vibration amplitude along the $\mathrm{y}$-axis (along the unbalance mass vertical to the shaft) during balance and unbalance conditions show significant increase in amplitude which mainly due to the simulated unbalance mass. The unbalance mass affects the vibration level along the $y$-axis more than along the $x$-axis, an expected behaviour.

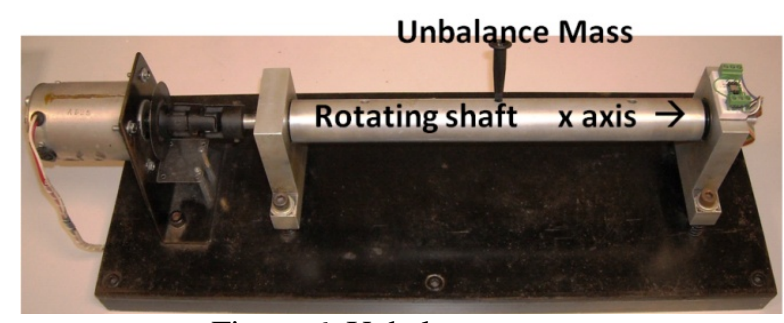

Figure 6. Unbalance mass.
Tabel 1.

Balance condition.

\begin{tabular}{|c|c|}
\hline $\mathrm{X}$ axis (mg) & Y axis (mg) \\
\hline-19 & -32 \\
\hline 176 & 16 \\
\hline 251 & 64 \\
\hline-92 & 16 \\
\hline-196 & 64 \\
\hline 168 & 0 \\
\hline-196 & 32 \\
\hline 236 & 16 \\
\hline-172 & 24 \\
\hline-20 & 72 \\
\hline 92 & 16 \\
\hline-244 & 64 \\
\hline-180 & 8 \\
\hline-75 & -40 \\
\hline 131 & 48 \\
\hline-59 & -24 \\
\hline-4 & 64 \\
\hline 43 & 72 \\
\hline-3 & -40 \\
\hline 24 & -16 \\
\hline-19 & -32 \\
\hline-204 & 56 \\
\hline
\end{tabular}

Table 2.

Unbalance condition.

\begin{tabular}{|c|c|}
\hline $\mathrm{X}$ axis (mg) & Y axis (mg) \\
\hline 180 & 48 \\
\hline-316 & -64 \\
\hline-148 & -40 \\
\hline 203 & 24 \\
\hline-211 & -80 \\
\hline-108 & 32 \\
\hline 124 & 16 \\
\hline-168 & -176 \\
\hline 28 & -192 \\
\hline-147 & -168 \\
\hline 124 & 40 \\
\hline-11 & -64 \\
\hline-51 & -88 \\
\hline-19 & -88 \\
\hline 348 & -88 \\
\hline-147 & -112 \\
\hline-152 & 56 \\
\hline-176 & -152 \\
\hline-176 & -136 \\
\hline 187 & 72 \\
\hline 11 & 144 \\
\hline
\end{tabular}




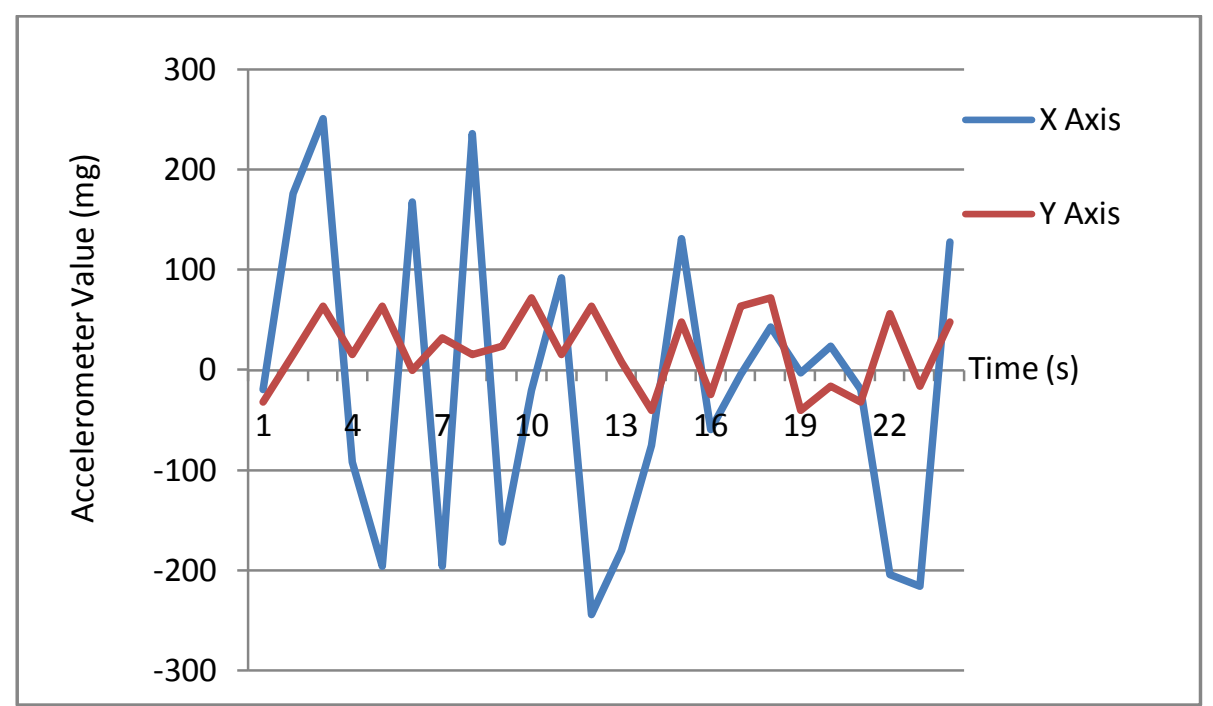

Figure 7. Accelerometer outputof balance condition experiment.

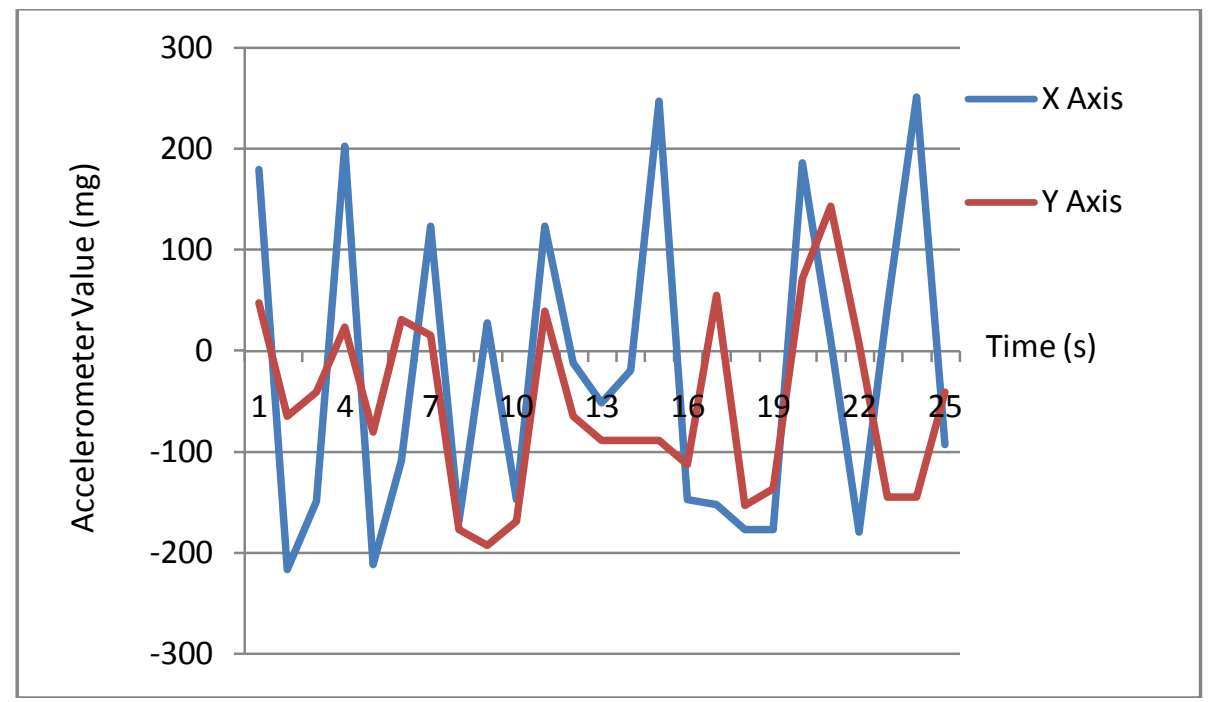

Figure 8. Accelerometer output of unbalance condition experiment.

Due to the limitation of the accelerometer frequency resolution of the memsic2125, only its statistical amplitude is used to monitor vibration amplitude.

Figure 8 shows the data output of accelerometer in unbalance condition. It means there is additional mass on the system of the rotating machine.

\section{Conclusion}

The vibration monitoring system for a model of rotating machine demonstrates the effect of vibration as expected. The vibration from the machine in balance and imbalance conditions can be monitored, transmitted, and processed in real time. It means that the mechanical and electrical parts are working properly. The experiment is also able to successfully demonstrate the condition of the machine and its effect to vibration level.

The low-cost Memsic2125 accelerometer sensor that is implemented using $g$ force formula gives $\mathrm{g}$ force digital output signal according to the vibration of the rotating machine. The Memsic2125 accelerometer output signal is already readable by the microcontroller, because the output signal is in PWM signal. Data are successfully sent to the software plotter via serial communication.

Overall, low cost system can be used to improve maintenance systems cost effectively, especially for older rotating machines without built-in vibration sensors. For higher quality output, new accelerometers with wider bandwidth (in range of $\mathrm{kHz}$ ) and higher g level (25 g or more) are highly favourable for detailed analysis. 


\section{REFERENCES}

[1] J. L. Taylor, Vibration Analysis Handbook, 1st ed., Huston: Gulf Publishing Company, 2008.

[2] C.D. Johnson, Process Control Intrumentation Technology, 8th ed., Houston: Pearson Education, 2006,pp. 246257

[3] G. Rizzoni, Principles and Applications of Electrical Engineering, 5th ed., New York: McGraw-Hill,2007, pp. 762

[4] Datasheet: Memsic2125 Dual-Axis Accelerometer (\#28017), v2.0 29 January 2009, pp.1-3, [Online]. Available: http://www.parallax.com

[5] P. Irasari, A.S. Nugraha, M. Kasim, "Analisis Getaran pada Generator Magnet Permanen 1 kW Hasil Rancang Bangun Pusat Penelitian Tenaga Listrik dan Mekatronik", Journal of Mechatronics, Electrical Power and Vehicular Technology, vol. 1, no.1.

[6] Didik R. Santoso, "A Simple Instrumentation System for Large Structure
Vibration”, Jurnal Telkomnika, 20108.3.12.10.08, ISSN: 1693-6930, e-ISSN: 2087-278X, [Online]. Available: http://telkomnika.ee.uad.ac.id

[7] Yusuf Yesilce, "Effect of Axial Force on the Free Vibration of Reddy-Bickford Multispan Beam Carrying Multiple Spring-mass Systems", Journal of Vibration and Control 2010, [Online]. Available: http://jvc.sagepub.com/content/16/1/11

[8] Wilfried Reimche, Ulrich Südmersen, Oliver Pietsch, Christian Scheer, Fiedrich (2003, June 2-6). "Basics of Vibration Monitoring for Fault Detection and Process Control", Wilhelm Bach University of Hannover, Germany, Proceeding Rio de Janeiro - RJ Brasil

[9] J Michael Robichaud, P.Eng., "Reference Standards for Vibration Monitoring and Analysis”, [online]. Available: http://www.bretech.com/reference/Referenc e\%20Standards\%20for\%20Vibration\%20M onitoring\%20and\%20Analysis.pdf 